\title{
Perancangan dan Pembuatan Program Notifikasi Masa Aktif Kompas Gramedia Value Card (KGVC) sebagai Media Informasi Customer (Studi Kasus pada Toko Buku Gramedia Madiun)
}

\author{
Panggede Wahyudistrio ${ }^{1}$; Fatim Nugrahanti ${ }^{2}$ \\ Program Studi S1 Teknik InformatikaSekolah Tinggi Teknik Dharma Iswara Madiun \\ Jl. Auri No. 14-16 Madiun Telp.0351-469128 \\ 1panggede@gmail.com; ${ }^{2}$ fatimmadiun@yahoo.co.id
}

\begin{abstract}
ABSTRAK
Kompas Gramedia (KG), bekerja sama dengan Bank Central Asia (BCA) menerbitkan Kompas Gramedia Value Card (KGVC), yang memasuki tahun ketiga memiliki member 400.000 orang. Selain berfungsi sebagai kartu identitas, KGVC juga sebagai alat bayar di 13 unit bisnis yang tergabung diantaranya, Toko Buku Gramedia, Grup Hotel Santika, Harian Kompas, Kontan, Warta Kota, Tabloid Nova, Majalah Bobo, Bentara Budaya, ELTI, Gramedia Publishers, Tribun Jogja dan The Jakarta Post.
\end{abstract}

Kata Kunci: KGVC, Waterfall, Media Informasi Customer.

\section{PENDAHULUAN}

Perkembangan informasi mempunyai peranan yang sangat penting didalam suatu usaha. Informasi yang cepat, tepat dan akurat akan memberikan hasil yang terbaik bagi perusahaan itu sendiri. Sistem informasi merupakan salah satu bagian penting bagi perusahaan untuk meningkatkan produktifitas baik dalam memperoleh informasi, mengolah dan menggunakan informasi tersebut terutama untuk kepentingan intern perusahaan Informasi dapat diperoleh baik secara manual maupun secara terkomputerisasi. Setiap perusahaan perlu adanya sistem yang membantu mempermudah pengerjaan di dalam perusahaan tersebut.

Gramedia merupakan salah satu Toko Buku ternama di Kota Madiun, bahkan di seluruh Indonesia. Toko Buku Gramedia Madiun menyediakan buku-buku dari berbagai penerbit dan penulis dari seluruh nusantara. Toko buku sangatlah berperan penting dalam dunia pendidikan khususnya para pelajar dan mahasiswa. Tidak hanya penting untuk pendidikan, dewasa ini juga banyak penulis yang berlomba untuk membuat sebuah karya dan dijual di pasaran. Untuk itu Toko Buku Gramedia di Kota Madiun ini sangatlah membantu.

Dalam study kasus ini penulis akan merancang suatu sistem yang akan membatu dalam meningkatkan mutu pelayanan customer, dengan membuat sebuah program yaitu notifikasi masa aktif KGVC melalui SMS Gateway sebagai media informasi customer, tujuannya adalah untuk memberi pesan notifikasi kepada customer mengenai masa aktif KGVC yg akan habis, selain itu juga memberi informasi mengenai promo di Toko Buku Gramedia Madiun.

\section{KAJIAN PUSTAKA \\ Sistem}

Menurut Norman L.Enger dalam Ulfa Pauziah (2013:190), sistem adalah sekelompok elemen-elemen yang saling berintegrasi dengan maksud yang sama untuk mencapai suatu tujuan, suatu organisasi seperti perusahaan atau suatu area fungsional.

Sedangkan menurut Jogiyanto dalam Dyah (2013:2), terdapat dua kelompok pendekatan dalam mendefinisikan sistem, yaitu yang menekankan pada prosedurnya dan yang menekankan pada komponen atau elemennya. Sistem dapat diartikan sebagai kumpulan dari beberapa komponen yang saling berhubungan satu dengan yang lainnya membentuk satu kesatuan untuk mencapai tujuan tertentu. Menurut Bonnie dkk dalam Tituk (2016:2),untuk mencapai tujuan tertentu didalam sistem terkandung tiga elemen penting, yaitu rangkaian komponen, interaksi, kerja sama dan yang terakhir adalah tujuan.

\section{SubSistem}

Suatu sistem dapat didefinisikan sebagai suatu kesatuan yang terdiri dari dua atau lebih komponen atau subsistem yang berinteraksi untuk mencapai tujuan.Suatu sistem dapat terdiri dari beberapa bagian-bagian sistem atau 
subsistem.Sebagai contoh sistem komputer, terdiri dari subsistem perangkat keras dan subsistem perangkat lunak, masing-masing subsistem dapat berisi lagi ubsistemsubsistem lain atau terdiri dari komponenkomponen pendukung sistem itu sendiri Tata Sutabri (2012:11).

Konsep sebuah sistem menuntut perancangan mempertimbangkan suatu sistem sebagai sebuah kesatuan.Kesatuan sistem terlalu besar untuk dianalisis secara rinci.Oleh karenanya, sistem dibagi atau diuraikan atas beberapa subsistem.Menurut Norman L. Enger dalam bukunya mengatakan bahwa subsistem adalah serangkaian kegiatan yang dapat ditentukan identitasnya yang berhubungan dalam suatu sistem.Gordon B Davis dalam bukunya mengatakan bahwa sistem terbagi atas beberapa subsistem-subsistem. Batasan dan penghubung atau interface didalam suatu sistem ditelaah secara cermat untuk penjamin bahwa hubungan antar subsistem di definisikan secara jelas dan bahwa jumlah semua subsistem merupakan keseluruhan sistem Tata Sutabri (2012:12).

\section{Karakteristik Sistem}

Menurut Saraswati (2013:35) suatu sistem mempunyai karakteristik atau sifatsifat yang tertentu, yaitu mempunyai komponen-komponen (components), sistem data (boundary), lingkungan luar sistem (environments), penghubung (interface), masukan (input), keluaran (output), pengolahan (proses) dan sasaran (objectives) atau tujuan (goal).

\section{Sistem Informasi}

Sistem informasi adalah sekumpulan hardware, software, brainware, prosedure atau aturan yang diorganisasikan secara integral untuk mengolah data menjadi informasi yang bermanfaat guna memecahkan masalah dan pengambilan keputusan (Witarto dalam Dedi 2013:2).

Menurut Witarto dalam Rini (2014:20), sistem informasi merupakan sistem yang berisi jaringan SPD (Sistem Pengolahan Data), yang dilengkapi dengan kanal-kanal komunikasi yang digunakan dalam sistem organisasi data.

\section{KGVC}

Kompas Gramedia (KG) bekerja sama dengan Bank Central Asia (BCA) menerbitkan Kompas Gramedia Value Card - Flazz (KGVC - Flazz). Tiga tahun sudah KGVC-Flazz masuk dalam keluarga besar KG yang saat ini sudah memiliki member lebih dari 400.000 orang.

Dalam rangka memberikan kenyamanan dan mempermudah transaksi bagi pelanggan KG secara keseluruhan, KGVC-Flazz, selain berfungsi sebagai kartu identitas keanggotaan juga sekaligus sebagai alat bayar yang didukung oleh Flazz BCA. Kini terdapat 13 unit bisnis yang tergabung di KGVC, Toko Buku Gramedia, Grup Hotel Santika, Harian Kompas, Kontan, Warta Kota, Tabloid Nova, Majalah Bobo, Bentara Budaya, ELTI, Gramedia Publishers, Tribun Jogja, The Jakarta Post dan adapun kartu keluaran tebaru dari KG Value Card yaitu Kompasiana.

\section{METODOLOGI PENELITIAN}

Langkah-langkah yang dijalankan dalam menempuh penelitian ini diawali dengan penggalian dan pengumpulan data, pengajuan penelitian pada pihak Toko Buku Gramedia Madiun, analisa data, perancangan dan penerapan.

\section{ANALISA DAN PERANCANGAN Flowchart Sistem Yang berjalan}

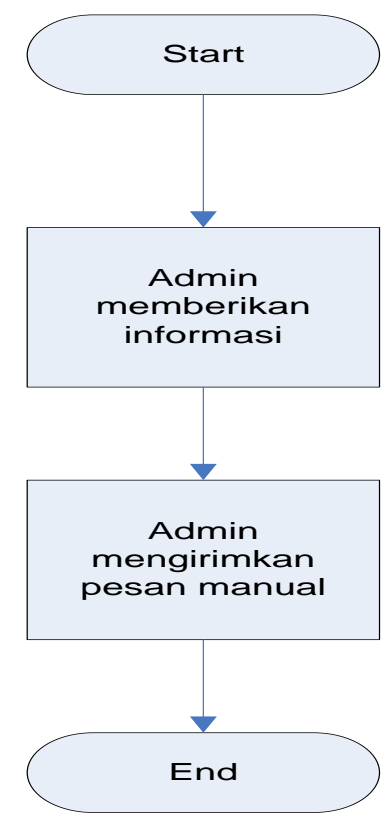

Gambar 1 Flowchart Sistem Yang Berjalan 


\section{Flowchart yang diusulkan}

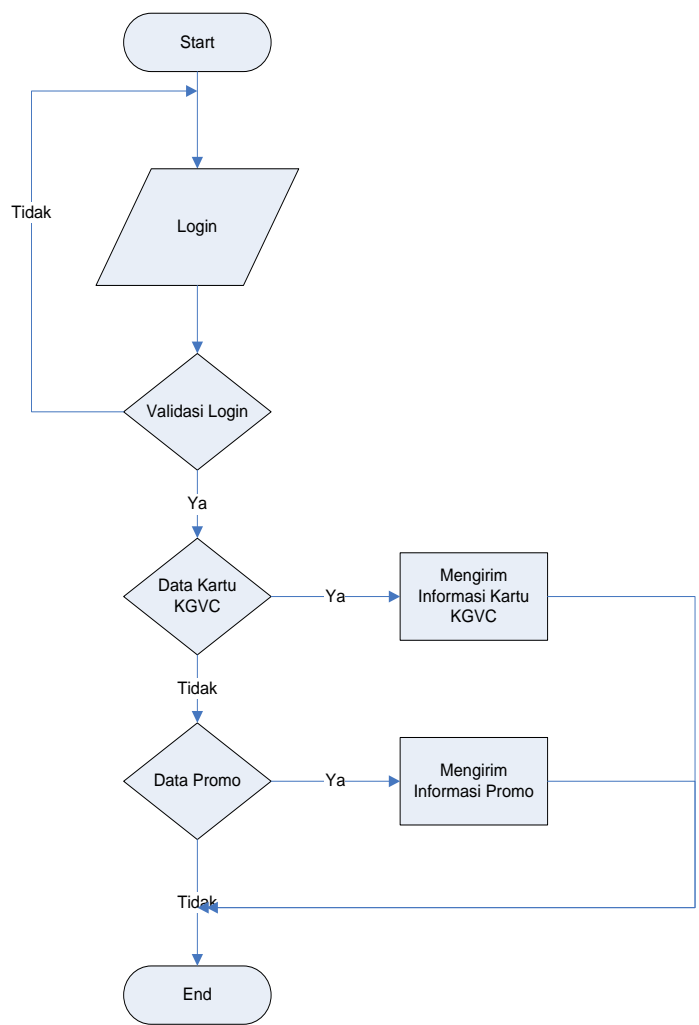

Gambar 2 Flowchart yang diusulkan

\section{DFD Konteks}

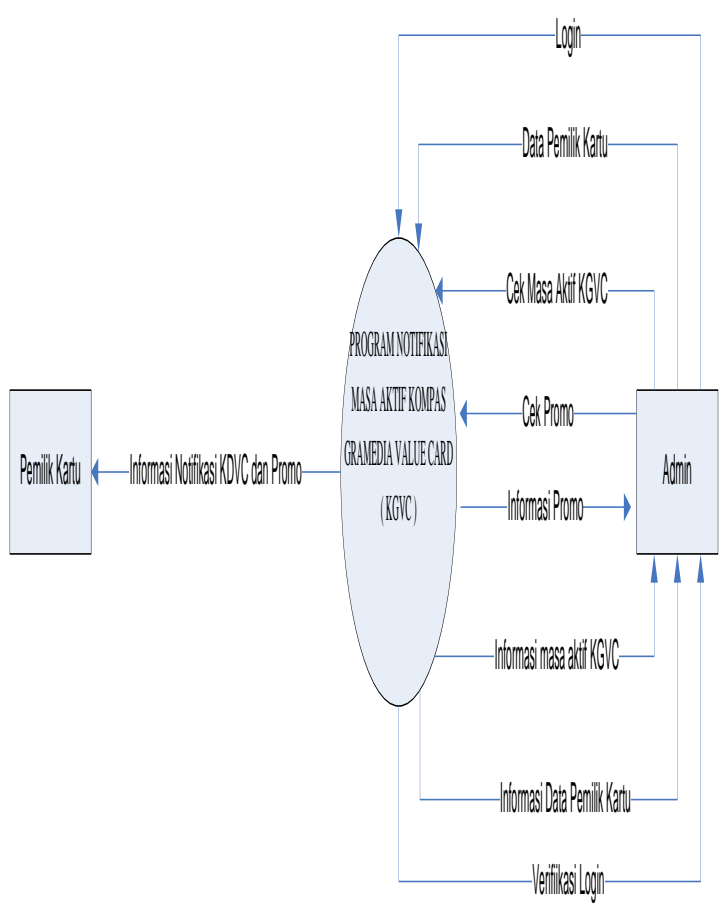

Gambar 3 DFD Konteks

\section{DFD Level 1}

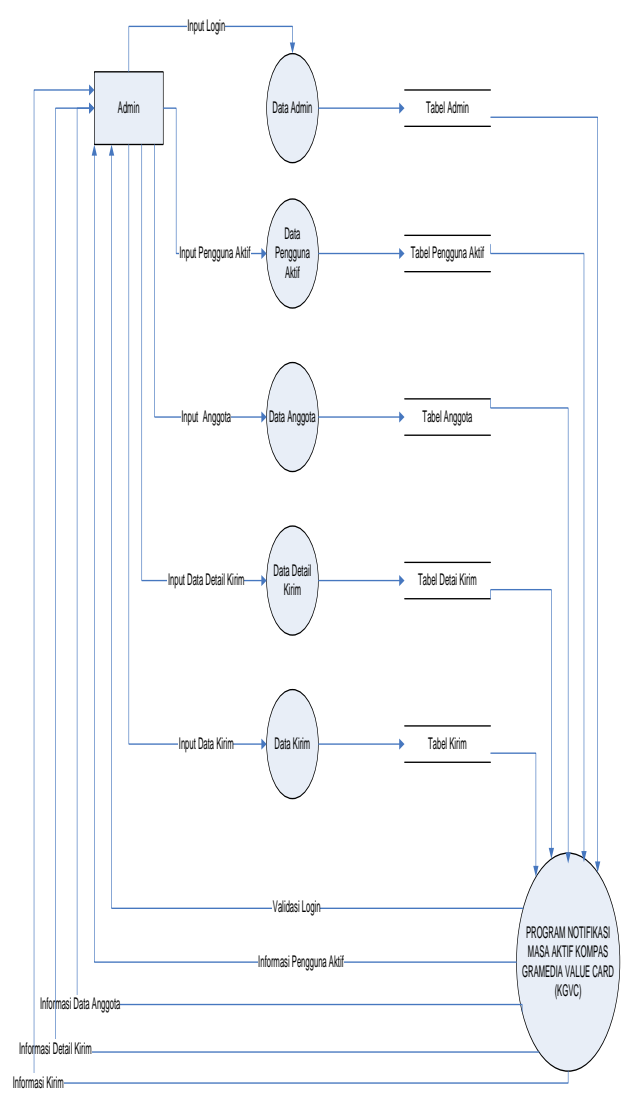

Gambar 4 Data Flow Diagram

ERD
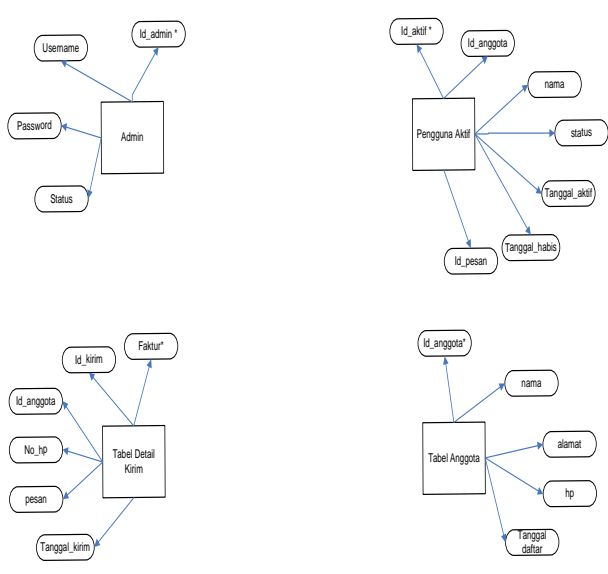

Gambar 5 ERD

Panggede, Perancangan dan Pembuatan Program Notifikasi Masa Aktif Kompas Gramedia Value Card.... 


\section{Implementasi Sistem}

a. Halaman Login

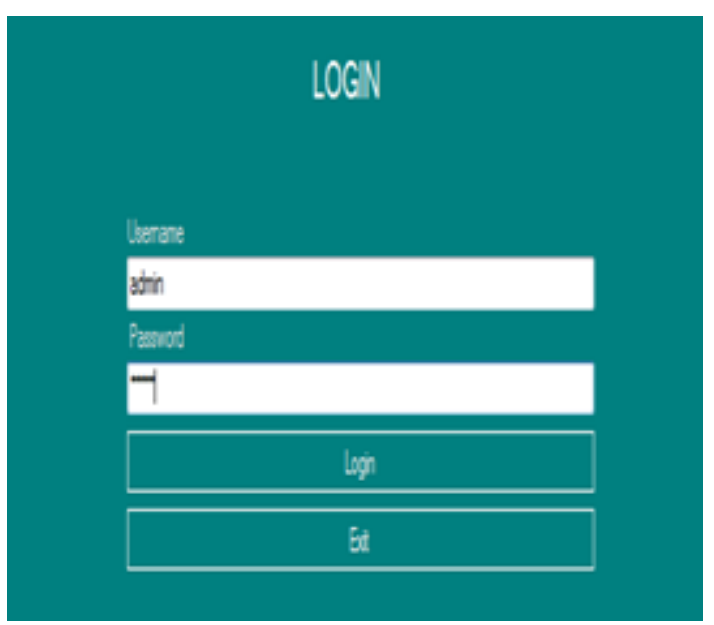

Gambar 6 Halaman Log In

b. Halaman Menu Utama

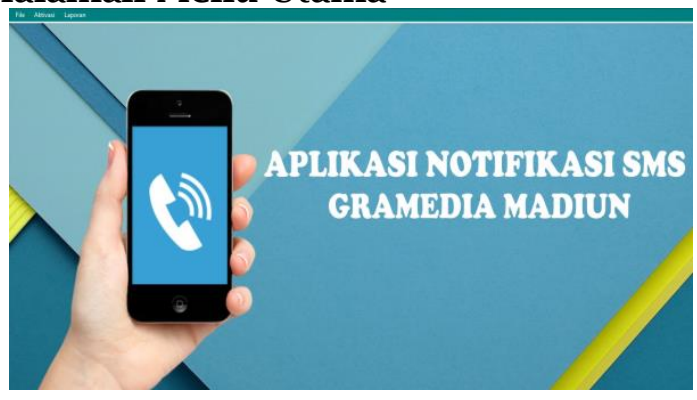

Gambar 7 Halaman Menu Utama

\section{c. Menu Anggota}

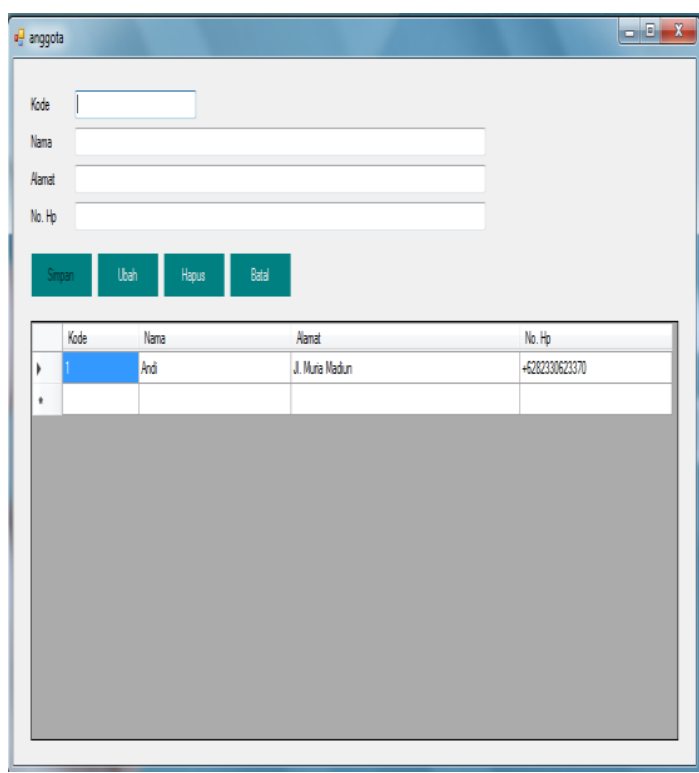

Gambar 8 Menu Anggota

\section{d. Menu Aktivasi}

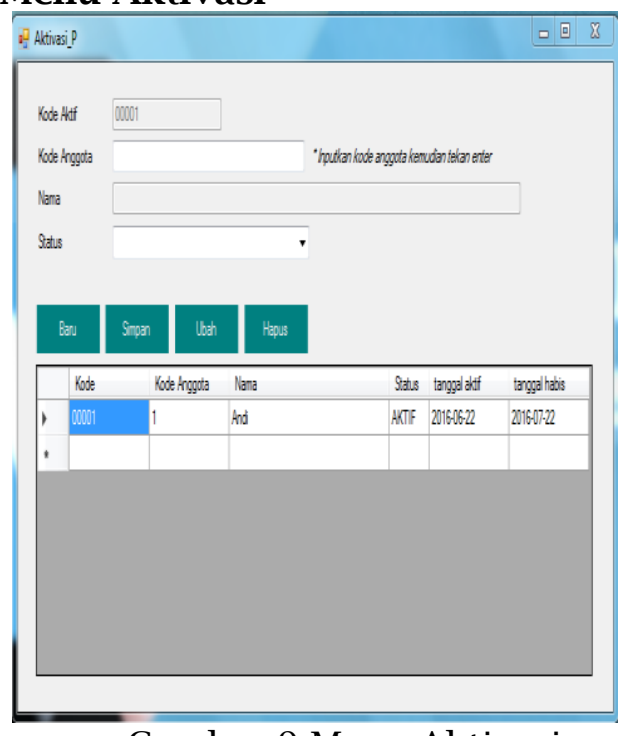

Gambar 9 Menu Aktivasi

e. Menu pesan

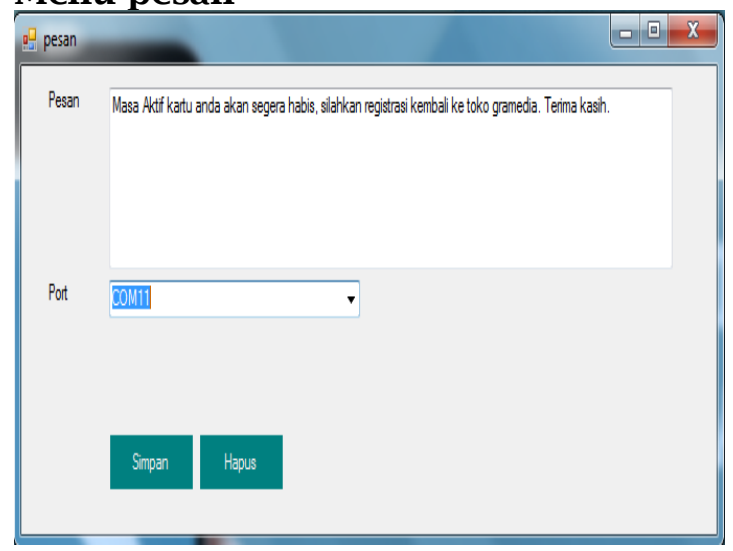

Gambar 10 Menu Pesan

\section{f. Kirim Pesan}

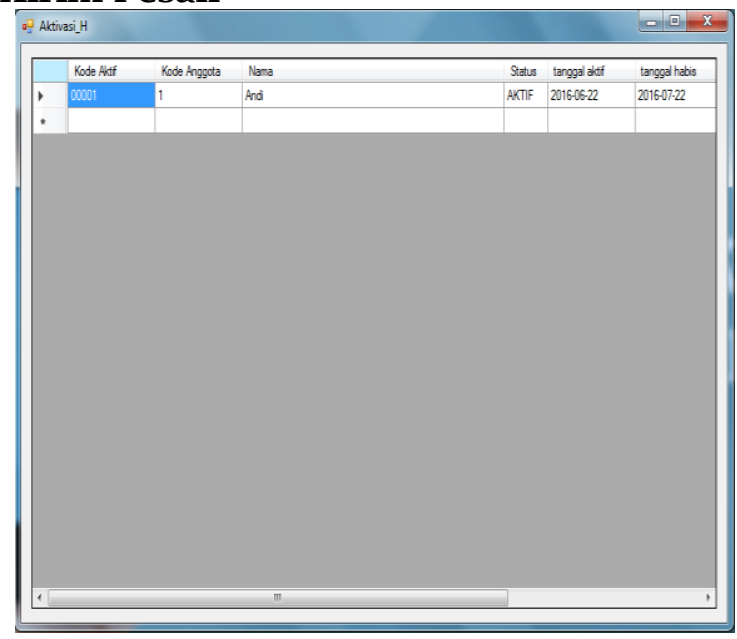

Gambar 11 Kirim Pesan

Panggede, Perancangan dan Pembuatan Program Notifikasi Masa Aktif Kompas Gramedia Value Card.... 


\section{g. POP UP Pesan}

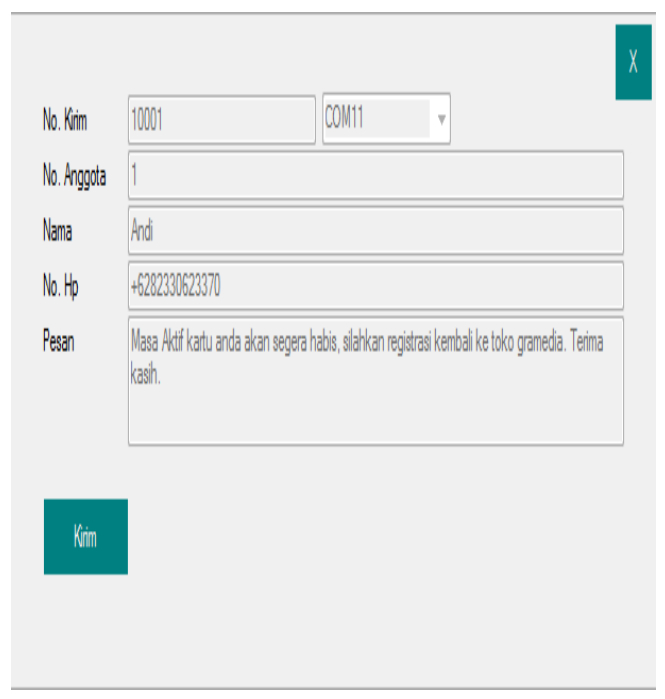

Gambar 12 POP UP Pesan

\section{h. Report Pesan}

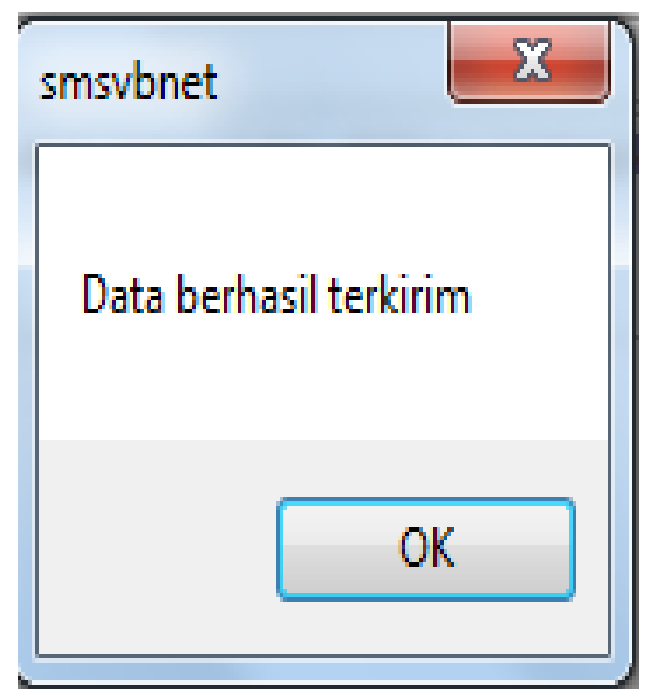

Gambar 13 Report Pesan

\section{i. Laporan Data Anggota}

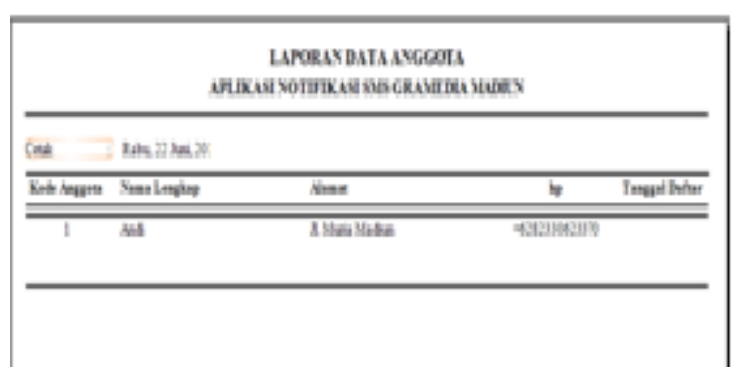

Gambar 14 Laporan Data Anggota

\section{j. Laporan Pesan Terkirim}

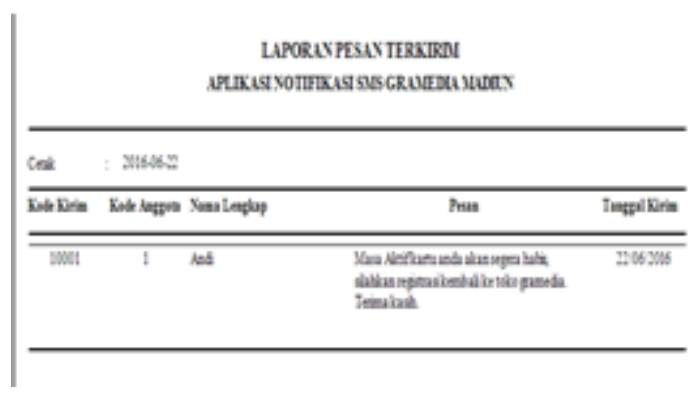

Gambar 15 Laporan Pesan Terkirim

\section{PENUTUP}

1. Aplikasi ini mempermudah admin dalam menganalisa dan melihat masa aktif kartu customer yang aktif dan tidak aktif.

2. Aplikasi ini menjadikan customer mengetahui kapan masa aktif kartu KGVC nya telah habis dan mengetahui promo terbaru pada toko Gramedia Madiun.

3. Aplikasi ini menjadikan management pengolahan kartu KGVC dan promo barang menjadi terkomputerisasi.

4. Semua proses dalam laporan pesan notifikasi, laporan anggota pemegang kartu KGVC dapat dilihat secara detail dan pencetakan laporan dapat dilakukan pada aplikasi ini.

\section{Saran}

1. Diharapkan dapat dilakukan eksplorasi terhadap kinerja sistem sms gateway lebih lanjut, sehingga dapat memberikan struktur elemen sistem terbaik yang dapat memberikan performance yang terbaik pula.

2. Software ini diharapkan kedepannya dapat diakses menggunakan website untuk diakses dari jarak jauh apabila ada keperluan untuk pengawasan dan melihat laporan dari program itu sendiri.

\section{DAFTAR PUSTAKA}

Syaifudin, Purnama, B, E, Wardati, I, U. 2013.Sistem Informasi Penggajian Karyawan Pada Toko Winscom Kabupaten Pacitan Dengan Menggunakan Program PHP. Indonesian Journal On Networking and Security (IJNS). ISSN: 2302-5700. 
Nurhanafi, A. 2014.Sistem Informasi Simpan Pinjam Pada Koperasi Sari Mulyo Kecamatan Ngadirojo.Indonesian Journal On Networking and Security(IJNS). ISSN: 2302-5700 (Print) 2354-6654 (Online).

I Gusti Made Karmawan. 2014.Perancangan Sistem Informasi Serba Usaha Pada Koperasi Tangerang. Jakarta. ComTech. Vol. 5 ISSN: 2087-1244.

Anggoro, D dkk.2015. Rancangan Sistem Informasi Koperasi Simpan Pinjam Guru Dan Pegawai Pada Koperasi Smk Manggala Tangerang.Seminar Nasional Teknologi Informasi dan Komunikasi (SENTIKA).Yogyakarta. ISSN: 2089-9815.

Hidayat, R. 2014. Sistem Informasi Ekspedisi Barang Dengan Metode E-CRM Untuk Meningkatkan Pelayanan Pelanggan. Jurnal Sisfotek Global. ISSN: 20881762 Vol. 4 No. 2.

Yuliawan, Y, M.J. Sunarto, D, Soebijono, T. 2013. Pengembangan Sistem Informasi Pendataan Jemaat Gereja Masehi Advent Hari Ketujuh Konferens Jawa Kawasan Timur Berbasis Web.JSIKA. ISSN: 2338-137X Vol 2, No 2.

Sovia, R, Febio, J. Maret 2011. Membangun Aplikasi E-Library Menggunakan Html, Php Script, Dan Mysql Database. Jurnal Teknologi Informasi \& Pendidikan. ISSN: 2086-4981 Vol. 3 No. 1.
Pauziah, U. 2013. Perancangan Sistem Pendataan Penduduk Pada Kelurahan Cililitan Jakarta Timur Berbazis Delphi. Faktor Exacta, 6(3): 189-199. ISSN: 1979-276X.

Fathansyah. 2012. Basis Data. Informatika Bandung. ISBN : 978-602-8758-53-6

Wahana, Westriningsih (Ed.). 2012. Panduan Aplikasi \& Solusi (PAS) Membangun Aplikasi Bisnis dengan NetBeans 7. Yogyakarta: Andi

Saputra, A. 2013.Step by Step Membangun Aplikasi Bioskop dan SMS untuk Panduan Skripsi. PT Elex Media Komputindo, Jakarta. ISBN: 9286020225104

Rohayati, M. 2014. Membangun Sistem Informasi Monitoring Data Inventory Di Vio Hotel Indonesia.Jurnal Ilmiah Komputer dan Informatika (KOMPUTA). Edisi 1 Volume 1, ISSN : 2089-9033

Pascapraharastyan, R, A. 2014. Rancang Bangun Sistem Informasi Manajemen Arsip Rumah Sakit Bedah Surabaya Berbasis Web. Jurnal Sistem Informasi. JSIKA Vol 3, No 1 ISSN 2338-137X

Sutabri, T. 2012. Konsep Sistem Informasi. Penerbit ANDI. Yogyakarta. 